\title{
Isolation and characterization of polymorphic microsatellite markers for blue fox (Alopex lagopus)
}

\author{
Y.M. Li, P.C. Guo, J.Y. Lu, C.Y. Bai, Z.H. Zhao and S.Q. Yan \\ College of Animal Science, Jilin University, Changchun, China \\ Corresponding author: S.Q. Yan \\ E-mail: yansq@jlu.edu.cn.
}

Genet. Mol. Res. 15 (2): gmr. 15027990

Received November 4, 2015

Accepted February 12, 2016

Published June 3, 2016

DOI http://dx.doi.org/10.4238/gmr.15027990

\begin{abstract}
The blue fox, belonging to the family Canidae, is a coat color variant of the native arctic fox (Alopex lagopus). To date, microsatellite loci in blue fox are typically amplified using canine simple sequence repeat primers. In the present study, we constructed an $(\mathrm{AC})_{\mathrm{n}}$ enrichment library, and isolated and identified 17 polymorphic microsatellite markers for blue fox. The number of alleles per locus is from two to seven based on 24 examined individuals. The expected and observed heterozygosities were in the range of 0.3112 to 0.8236 and 0.2917 to 0.8750 , respectively. The polymorphic information content per locus ranged from 0.2583 to 0.8022 . These polymorphic markers can be useful for future population genetic studies of both farmed blue foxes and wild arctic foxes.
\end{abstract}

Key words: Arctic fox; Microsatellite marker; Genetic polymorphism 


\section{INTRODUCTION}

The arctic fox (Alopex lagopus), belonging to the Canidae family, lives in some of the most frigid and extreme environments on the planet. The blue fox, a color variant of the arctic fox, has a uniform dark blue coat color in summer. In winter, blue fox does produce a lighter colored coat compared to the summer coat, although it is far more pigmented compared to the white coat of the native arctic fox (Våge et al., 2005). The blue fox has been domesticated providing fur for the clothing industry (Nowacka-Woszuk et al., 2013).

Microsatellites, or simple sequence repeats (SSRs), are stretches of DNA consisting of short tandem-repeated motifs that are 1-6 bp in length and ubiquitous in eukaryotes (Beckman and Weber, 1992; Zhao and Kochert, 1993). Because of their high polymorphism, co-dominance, and abundance in the genome of eukaryotes, microsatellite markers have been extensively used in genetic mapping (Kukekova et al., 2004), forensics (Lindqvist et al., 1996), evolutionary studies, and population genetic analyses (Korrida et al., 2012; Wang et al., 2014). To date, the microsatellite markers available for arctic fox were derived from cross-species amplifications with canine SSR primers (Fredholm and Winterø, 1995; Rogalska-Niznik et al., 2003; Szczerbal et al., 2003; Dalén et al., 2006; Geffen et al., 2007). In the present study, we isolated and characterized 17 polymorphic microsatellite markers for arctic fox from an (AC) $)_{n}$ enrichment library.

\section{MATERIAL AND METHODS}

All experiments were performed in accordance with the guidelines of animal care, established by the Jilin University Animal Care and Use Committee. Muscle tissue from 24 farmed blue foxes was randomly collected from three farms in Jilin, Hebei, and Shandong, China. Genomic DNA was isolated from muscle tissue using the TIANamp Genomic DNA Kit (TIANGEN, Beijing, China).

In order to obtain a higher number of blue fox microsatellite markers, a partial DNA library enriched for (AC) motifs was constructed, following a combination of modified procedures (Novelli et al., 2006; Yan et al., 2013). Briefly, the genomic DNA from one male individual was digested with the restriction enzyme Sau3AI and fragments ranging from 300 to $1000 \mathrm{bp}$ were recovered from a $1.5 \%$ agarose gel. The recovered fragments were

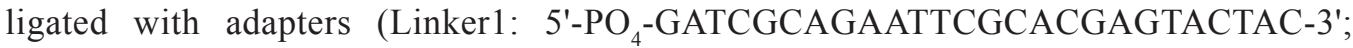
Linker2: 5'-GTAGTACTCGTGCGAATTCTGC-3') by incubation at $16^{\circ} \mathrm{C}$ overnight with T4 DNA ligase (TAKARA, Dalian, China). The fragments containing (TG) tandemrepeated sequences were enriched by hybridizing to biotin-(AC) ${ }_{13}$ oligonucleotides and separated with streptavidin magnetic beads (Promega, Madison, WI, USA). Subsequently, a polymerase chain reaction (PCR) was carried out with Linker2 as primer and the final eluate $(0.5 \mu \mathrm{L})$ served as template. The PCR conditions were as follows: $95^{\circ} \mathrm{C}$ for 2 min followed by 30 cycles at $94^{\circ} \mathrm{C}$ for $30 \mathrm{~s}$, an annealing temperature of $58^{\circ} \mathrm{C}$ for 30 $\mathrm{s}$, and $72^{\circ} \mathrm{C}$ for $1 \mathrm{~min}$, with a final extension at $72^{\circ} \mathrm{C}$ for $15 \mathrm{~min}$. The PCR products were purified, ligated to a pMD18-T vector (TaKaRa), and transformed into Escherichia coli DH5 $\alpha$ competent cells. To identify the positive clones, we utilized bacilli as the template and Linker2 as the primer for PCR amplification. Clones containing inserts were sequenced by Sangon Biotech (Shanghai, China). 
PCR primers were designed based on the flanking DNA sequences of clones which contained $(\mathrm{AC})_{\mathrm{n}}$ or $(\mathrm{TG})_{\mathrm{n}}$ tandem repeat sequences, using Primer Premier 5.0 (Premier Biosoft International, Palo Alto, CA, USA). The PCR products of all primers were expected to be between 100 and $400 \mathrm{bp}$ in size. In order to examine the polymorphisms, a M13 (-21) tail (5'-TGTAAAACGACGGCCAGT-3') was added to all the forward primers (Schuelke, 2000). The M13 (-21) tag primers were labeled with dyes FAM, HEX, or TAMARD. To evaluate the PCR primers, preliminary analyses were firstly performed using only four individuals. The polymorphic information for the loci that showed specific amplifications was then assessed in all 24 individuals. The PCR was performed in a 25$\mu \mathrm{L}$ reaction volume containing $10 \mathrm{ng}$ genomic DNA, $0.1 \mathrm{mM}$ each dNTP, $0.5 \mathrm{U}$ Taq polymerase (TaKaRa), $0.25 \mu \mathrm{M}$ M13 (-21) tailed forward primer, $1 \mu \mathrm{M}$ M13 (-21) tag primer, and $1 \mu \mathrm{M}$ reverse primer. The PCR reaction conditions were as follows: a 5-min denaturation step at $95^{\circ} \mathrm{C}$ followed by 30 cycles of $30 \mathrm{~s}$ at $94^{\circ} \mathrm{C}, 30 \mathrm{~s}$ at $58^{\circ} \mathrm{C}$, and $30 \mathrm{~s}$ at $72^{\circ} \mathrm{C}$, followed by a final extension of $15 \mathrm{~min}$ at $72^{\circ} \mathrm{C}$.

Genotyping was performed using an ABI 3730 DNA sequencer (Applied Biosystems, Foster City, CA, USA). Allele length was automatically estimated with GeneMapper $^{\circledR}$ software v. 4.0 according to the GeneScan-500 internal size standard (Applied Biosystems). The polymorphic information was assessed using the CERVUS 2.0 software (Marshall et al., 1998).

\section{RESULTS AND DISCUSSION}

Genomic DNA was successfully digested with the restriction enzyme Sau3A I and fragments ranging from 300 to $1000 \mathrm{bp}$ were recovered from the agarose gel. Because the recognition motif for Sau $3 \mathrm{AI}$ is only four bp (GATC), the restriction sites are widely distributed across mammalian genomes. This ensures both randomness and authenticity of the enriched microsatellite library.

PCR fragments amplified with Linker2 as primer were ligated to the pMD18-T vector and transformed into DH5 $\alpha$ competent cells. Of the 248 recombinants, 185 clones contained inserts. The sequencing analysis revealed that 134 clones contained more than five CA or TG repeats. Each fragment was given a name consisting of the prefix AL (Alopex lagopus) followed by a number. The number of CA or TG repeats in these clones ranged from 5 to 25 . Of the 134 clones, 83 had perfect motifs, 32 had imperfect motifs, and 19 had compound repeat motifs.

Primers were designed according to the flanking sequence of the 42 clones that contained more than 10 repeats. Out of all the primer pairs, 24 showed specific amplification and 17 loci were polymorphic in all 24 individuals tested in this study. The primer information, repeat motif, and the polymorphic parameters of the 17 loci are presented in Table 1. The number of alleles per locus ranged from two to seven. The expected and observed heterozygosities per locus ranged from 0.3112 to 0.8236 , with an average of 0.6598 , and from 0.2917 to 0.8750 , with an average of 0.6362 , respectively. The polymorphic information content per locus ranged from 0.2583 to 0.8022 , with an average of 0.5975 . In summary, the 17 polymorphic microsatellite markers developed in the present study may contribute to future studies on the population genetics of both farmed blue foxes and wild arctic foxes. 
Table 1. Characteristics of the polymorphic microsatellite markers developed for blue fox.

\begin{tabular}{|c|c|c|c|c|c|c|c|c|}
\hline Locus & Primer sequences $\left(5^{\prime} \rightarrow 3^{\prime}\right)$ & Repeat motif & $N_{\mathrm{A}}$ & $\begin{array}{l}\text { Size range } \\
(\mathrm{bp})^{*}\end{array}$ & $H_{\mathrm{E}}$ & $H_{\mathrm{O}}$ & PIC & $\begin{array}{l}\text { GenBank } \\
\text { No. }\end{array}$ \\
\hline AL704 & $\begin{array}{l}\text { F: GCACATTTCAGACTTGCCTACC } \\
\text { R: TACCAGTCCTCCAGAGAAACAG }\end{array}$ & $(\mathrm{CA})_{20}$ & 7 & $190-206$ & 0.8236 & 0.7500 & 0.7794 & KT965618 \\
\hline AL461 & $\begin{array}{l}\text { F: GTCATTGCCTGAAATCAAAAGT } \\
\text { R: CTTTGAAGTCACTGGGAGCTT }\end{array}$ & $(\mathrm{TG})_{20}$ & 5 & $247-265$ & 0.5567 & 0.4400 & 0.4768 & KT965619 \\
\hline AL304 & $\begin{array}{l}\text { F: TGCCATGGCTAGGAATTTAC } \\
\text { R: CAGGTGGGATTTTCGTGGA }\end{array}$ & $(\mathrm{AC})_{20}$ & 6 & $208-224$ & 0.8440 & 0.8333 & 0.8022 & KT965620 \\
\hline AL341 & $\begin{array}{l}\text { F: TAACATAGGACCTTTGGGAGC } \\
\text { R: TCTTTCCACCACACATTGGCTAC }\end{array}$ & $(\mathrm{TG})_{2} \mathrm{~T}(\mathrm{TG})_{8} \mathrm{AC}(\mathrm{TG})_{9}$ & 2 & $258-262$ & 0.4034 & 0.3750 & 0.3170 & KT965621 \\
\hline AL660 & $\begin{array}{l}\text { F: CTTTTCCAAATCCACCATTCTCC } \\
\text { R: GTGAGGTATGGGGCATTGTAG }\end{array}$ & $(\mathrm{AC})_{12} \mathrm{GC}(\mathrm{CA})_{5}$ & 5 & $218-238$ & 0.7349 & 0.7083 & 0.6734 & KT965622 \\
\hline AL90 & $\begin{array}{l}\text { F: TTTCGGGTGCCCCTAATAAC } \\
\text { R: TAAAGTGAGAGGCAATAAGGAATAC }\end{array}$ & $(\mathrm{AC})_{19}$ & 5 & $268-279$ & 0.6215 & 0.5417 & 0.5593 & KT965623 \\
\hline AL011 & $\begin{array}{l}\text { F: CAGGCAGCAAGGAGAAACAACT } \\
\text { R: CTTGATTATCTCCCTCTTTCTTTTG }\end{array}$ & $(\mathrm{TG})_{10}$ & 2 & $230-232$ & 0.3112 & 0.2917 & 0.2583 & KT965624 \\
\hline AL83 & $\begin{array}{l}\text { F: AGCACTTTTTTATGAATGCCCTT } \\
\text { R: CAGATTGTTGCCCAAGAGAGATAC }\end{array}$ & $(\mathrm{GT})_{16}$ & 5 & $274-284$ & 0.5168 & 0.5833 & 0.4615 & KT965625 \\
\hline AL118 & $\begin{array}{l}\text { F: GGAGGACACTTTAGATTTTGAGG } \\
\text { R: TTCAGAAAGGCAGCAATGTCAA }\end{array}$ & $(\mathrm{TG})_{16}$ & 5 & $238-246$ & 0.8094 & 0.7917 & 0.7593 & KT965626 \\
\hline AL651 & $\begin{array}{l}\text { F: GATCATGACCTGAGCCAAAGC } \\
\text { R: GTCACATGACCAAGCCAGGAC }\end{array}$ & $(\mathrm{CA})_{15}$ & 5 & $265-283$ & 0.5532 & 0.5417 & 0.4515 & KT965627 \\
\hline AL379 & $\begin{array}{l}\text { F: GCTGTTTGTCACTGTTGTGGATG } \\
\text { R: ATCTCAGCCCCATTCAAGTGTG }\end{array}$ & $(\mathrm{GT})_{15}$ & 6 & $252-268$ & 0.7926 & 0.8333 & 0.7432 & KT965628 \\
\hline AL827 & $\begin{array}{l}\text { F: TCTCATCTGGGTCCTTCGTCA } \\
\text { R: ATCCCCTGGAGGACGTGACA }\end{array}$ & $(\mathrm{CA})_{23}$ & 5 & $228-236$ & 0.7810 & 0.7500 & 0.7288 & KT965629 \\
\hline AL825 & $\begin{array}{l}\text { F: TAGGCAGGAGGTCTTAATAACA } \\
\text { R: GATCTCAGGGTTATGGGATAGAG }\end{array}$ & $(\mathrm{GA})_{7}(\mathrm{CA})_{12} \mathrm{~A}(\mathrm{CA})_{12}$ & 4 & $293-299$ & 0.7447 & 0.7083 & 0.6812 & KT965630 \\
\hline AL111 & $\begin{array}{l}\text { F: TTGGCAAGGAAATGGAAATCTC } \\
\text { R: CTAGGAGTAGAATTGCTCTTGGAC }\end{array}$ & $(\mathrm{AC})_{17}$ & 6 & $185-201$ & 0.7261 & 0.6667 & 0.6653 & KT965631 \\
\hline AL620 & $\begin{array}{l}\text { F: TTTTCAGCGAGTCAGGGTCA } \\
\text { R: CATTTCTAATTCCGTAACCAGTG }\end{array}$ & $(\mathrm{TG})_{4} \mathrm{~N}_{5}(\mathrm{GT})_{17} \mathrm{C}(\mathrm{AG})_{12}$ & 6 & $308-320$ & 0.8324 & 0.8750 & 0.7884 & KT965632 \\
\hline AL208 & $\begin{array}{l}\text { F: CCAGACTTGACCATTTGAACAG } \\
\text { R: ATGTAGGTCAGCCAGACTAAGAG }\end{array}$ & $(\mathrm{CA})_{17}$ & 3 & $256-262$ & 0.6587 & 0.6250 & 0.5707 & KT965633 \\
\hline AL349 & $\begin{array}{l}\text { F: GGAAGGACAGCCCATTCTAACTC } \\
\text { R: CCATGAACATACAAGCAGCCTAG }\end{array}$ & $(\mathrm{TG})_{12}$ & 4 & $415-425$ & 0.5062 & 0.5000 & 0.4416 & KT965634 \\
\hline
\end{tabular}

F, forward; R, reverse; $N_{\mathrm{A}}$, number of alleles; $H_{\mathrm{O}}$, observed heterozygosity; $H_{\mathrm{E}}$, expected heterozygosity; PIC, polymorphic information content; *size ranges include the additional 18-bp from the M13 (-21) tag.

\section{Conflicts of interest}

The authors declare no conflict of interest.

\section{ACKNOWLEDGMENTS}

Research supported by a project of the National Natural Science Foundation of China (\#31401979) and the Fundamental Research Funds of Jilin University (\#200903332).

\section{REFERENCES}

Beckman JS and Weber JL (1992). Survey of human and rat microsatellites. Genomics 12: 627-631. http://dx.doi. org/10.1016/0888-7543(92)90285-Z

Dalén L, Kvaløy K, Linnell JD, Elmhagen B, et al. (2006). Population structure in a critically endangered arctic fox population: does genetics matter? Mol. Ecol. 15: 2809-2819. http://dx.doi.org/10.1111/j.1365-294X.2006.02983.x

Fredholm M and Winterø AK (1995). Variation of short tandem repeats within and between species belonging to the Canidae family. Mamm. Genome 6: 11-18. http://dx.doi.org/10.1007/BF00350887

Geffen E, Waidyaratne S, Dalén L, Angerbjörn A, et al. (2007). Sea ice occurrence predicts genetic isolation in the Arctic fox. Mol. Ecol. 16: 4241-4255.http://dx.doi.org/10.1111/j.1365-294X.2007.03507.x

Korrida A, Jadallah S, Chbel F, Amin-Alami A, et al. (2012). Patterns of genetic diversity and population structure of the threatened Houbara and Macqueen's bustards as revealed by microsatellite markers. Genet. Mol. Res. 11: 3207-3221. http://dx.doi.org/10.4238/2012.September.12.4 
Kukekova AV, Trut LN, Oskina IN, Kharlamova AV, et al. (2004). A marker set for construction of a genetic map of the silver fox (Vulpes vulpes). J. Hered. 95: 185-194.http://dx.doi.org/10.1093/jhered/esh033

Lindqvist AK, Magnusson PK, Balciuniene J, Wadelius C, et al. (1996). Chromosome-specific panels of tri- and tetranucleotide microsatellite markers for multiplex fluorescent detection and automated genotyping: evaluation of their utility in pathology and forensics. Genome Res. 6: 1170-1176. http://dx.doi.org/10.1101/gr.6.12.1170

Marshall TC, Slate J, Kruuk LE and Pemberton JM (1998). Statistical confidence for likelihood-based paternity inference in natural populations. Mol. Ecol. 7: 639-655.http://dx.doi.org/10.1046/j.1365-294x.1998.00374.x

Novelli VM, Cristofani M, Souza AA and Machado MA (2006). Development and characterization of polymorphic microsatellite markers for the sweet orange (Citrus sinensis L. Osbeck). Genet. Mol. Biol. 29: 90-96. http://dx.doi. org $/ 10.1590 / \mathrm{S} 1415-47572006000100018$

Nowacka-Woszuk J, Salamon S, Gorna A and Switonski M (2013). Missense polymorphisms in the MC1R gene of the dog, red fox, arctic fox and Chinese raccoon dog. J. Anim. Breed. Genet. 130: 136-141. http://dx.doi.org/10.1111/ jbg.12005

Rogalska-Niznik N, Szczerbal I, Dolf G, Schläpfer J, et al. (2003). Canine-derived cosmid probes containing microsatellites can be used in physical mapping of Arctic fox (Alopex lagopus) and Chinese raccoon dog (Nyctereutes procyonoides procyonoides) genomes. J. Hered. 94: 89-93. http://dx.doi.org/10.1093/jhered/esg005

Schuelke M (2000). An economic method for the fluorescent labeling of PCR fragments. Nat. Biotechnol. 18: 233-234. http://dx.doi.org/10.1038/72708

Szczerbal I, Rogalska-Niznik N, Schelling C, Schläpfer J, et al. (2003). Development of a cytogenetic map for the Chinese raccoon dog (Nyctereutes procyonoides procyonoides) and the arctic fox (Alopex lagopus) genomes, using caninederived microsatellite probes. Cytogenet. Genome Res. 102: 267-271. http://dx.doi.org/10.1159/000075761

Våge DI, Fuglei E, Snipstad K, Beheim J, et al. (2005). Two cysteine substitutions in the MC1R generate the blue variant of the Arctic fox (Alopex lagopus) and prevent expression of the white winter coat. Peptides 26: 1814-1817. http:// dx.doi.org/10.1016/j.peptides.2004.11.040

Wang HL, Yang J, Boykin LM, Zhao QY, et al. (2014). Developing conversed microsatellite markers and their implications in evolutionary analysis of the Bemisia tabaci complex. Sci. Rep. 4: 6351.http://dx.doi.org/10.1038/srep06351

Yan SQ, Li YM, Bai CY, Ding XM, et al. (2013). Development and characterization of polymorphic microsatellite markers for Chinese raccoon dog (Nyctereutes procyonoides procyonoides). Genet. Mol. Res. 12: 6351-6355.http:// dx.doi.org/10.4238/2013.December.6.2

Zhao X and Kochert G (1993). Phylogenetic distribution and genetic mapping of a (GGC) microsatellite from rice (Oryza sativa L.). Plant Mol. Biol. 21: 607-614.http://dx.doi.org/10.1007/BF00014544 